\title{
The Impact of Information Systems on Port Performance: The Case of Morocco's Agadir Port
}

\author{
Soukaina Jouad, PhD \\ Mohammed Hicham Hamri, P.E.S.
}

ERETTLOG Laboratory, National School of Commerce and Management of Agadir, ENCG-Agadir, University Ibn Zohr, Morocco

\begin{abstract}
The objective of this research paper is therefore to examine the role of information systems in improving the port performance of Agadir. This study highlights how the port supply chain deploying information systems can improve performance by stimulating collaboration between multiple port operators. This research adopted a descriptive survey design. To achieve the objectives of the study, primary data was collected using a semi-structured questionnaire. The study concludes that the use of information systems reduce vessels stays and improves the productivity of ships at berths. Based on these results, the study concludes that the capacity to use and manage information systems in a much more effective and efficient way can improve the performance of the kingdom's port.
\end{abstract}

Keywords: Port, performance, information system, port supply chain, the port of Agadir

\section{Introduction}

In the context of globalization, the competitiveness of the port sector is essential. The multiplicity of actors makes the port logistics chains complex. In this context, the assessment of port performance is becoming essentials. Information systems are essential to the competitiveness of ports (Leonard Heilig, 2017).

The Souss-Massa Region is characterized by the export of agricultural products. Indeed, these products are affected by loading delays, which further prolong the transit time and delivery times for these products.

At the root of this situation, congestion in the port of Agadir is a complex phenomenon that is largely linked to poor planning and inadequate equipment. Information systems then constitute one of the solutions to support the transport network and logistics. The current port situation has been 
profoundly affected by the huge increase in the volume of maritime traffic caused by ever-higher levels of globalization.

Information technology plays a crucial role in the competitiveness of ports, as information is one of the key resources of any seaport. The modern transportation and logistics environment requires the implementation of information systems to maintain effective communication between members of the port community and improve performance.

The purpose of this study is to determine the role of information systems in improving port performance. More precisely, this paper presents a study of the effects of the use of information systems within the port of Agadir.

\section{Research problem}

The current port situation has been profoundly affected by the increase in the volume of commercial traffic. This increase is due in particular to the development prospects created by the port strategy following the port reform (Law 15-02).

The second phenomenon is that logistic become necessarily more complex to manage large volumes of traffic, manage risks and meet the expectations of different customers. Customers are at the heart of the port industry. They decide to expand their business or to set up elsewhere. Customers demand ever-higher levels of performance, lower costs and better quality of service. They want ports that are both consistent and constantly improving.

The third phenomenon is linked to congestion, which is a real problem for Moroccan ports.

The role of information technology in port systems has already been recognized by several researchers (kia and al., 2000). The integration of information systems into logistics has created competitive supply chains. The application of information systems in ports facilitates process management and flow control, which in turn minimizes data entry.

The research question we are trying to answer is: «Does the use of information systems contributes to the improvement of port performance? »

This study aims to explore the port sector in the region of Souss Massa, especially the port of Agadir.

This document is composed of two parts, a theoretical part and a second part will present a qualitative exploratory study, carried out using the semi-directive interview, thus testing the impact of the use of information systems on the performance of the port of Agadir, which represents our field of study. 


\section{The literature review of the research:}

\subsection{Information system in ports:}

According to (James A. O'Brien, 1995), an information system is a collection of people, procedures, and resources that collect information, transform it and distribute it within an organization. According to (Robert Reix, 2004), this is the association of human, material and software resources intended to collect, formalize, archive, browse, associate and disseminate information in this same organization ".

Reix recalls that "the diffusion of Enterprise resource planning (ERP) since the mid-1990s is part of a vast movement of organizational transformations, oriented towards a more transversal approach to processes." The study of information systems is therefore related to the organizational context in which it is used.

Information technologies play a necessary supporting role in the establishment and deployment of information systems.

Information and Communications Technology (ICT) is the main catalyst for internal and external integration. According to Sweeny and Evangelista (2005), the different types of ICT allow a level of internal integration (port community) and external as well as the integration of processes inside and outside the seaport. Hsu and Lalwani view the implementation of ICT as a facilitator of international transport, with emphasis on seaports as the focal points of transport chains.

\subsection{The port logistics chain: Port community}

According to Smit, the port community system is responsible for the provision, control, distribution and retention of data. Rodon and Ramis Pujol defined the port community system as an electronic platform that connects several systems operated by a variety of organizations that make up a port community.

A port community is made up of members, private and public entities, operating in the port area and providing port services. The entire port community acts in coordination to carry out all the port operations.

The complexity of the port community and a large number of data, messages, and documents highlight the need to implement integrated ICT systems to maintain competitiveness and improve the quality of service. A large number of stakeholders, depending on their activities and type of work, play a role in the functioning of the port community.

The port is also a link to it within the global supply chain (Meersman and al., 2009).

In addition to its main function as a place of transit, loading, and unloading of goods, the port has also become a real commercial center, 
logistics and a place of industrial exploitation of nations with maritime interfaces.

\subsection{Electronic data interchange}

As information systems do not necessarily speak the same language, common exchange standards have been created for all industrial or commercial communities.

The systems for port communities are generally based on the exchange data interchange.

Electronic data interchange (EDI) is a technique that replaces the physical exchange of documents between companies (orders, invoices, delivery notes...) by exchanges, in a standardized format, between computers connected by specialized links or through a (private) value-added network. The data is structured according to international technical standards of reference. For example, the sending by fax of an order and its input by an operator of the supplier company is replaced by the transmission of information that is routed to a computer of the supplier company capabilities to interpret the command.

The use of EDI can bring significant benefits in terms of the organization, such as faster data exchange, the reduction of communication costs, management of logistics processes, reduce delivery times, which improves the efficiency of the supply chain.

\subsection{Port performance}

Performance measurement is a key strategic activity for a port community, similar to any other company. A port must evaluate the efficiency and effectiveness of its operation. The performance evaluation is also done for promotional purposes, to increase the attractiveness of the port for new potential customers.

Out of these, Mentzer and Konrad (1991) define performance as an investigation of effectiveness and efficiency in the accomplishment of a given activity and where the assessment is carried out concerning how well the objectives have been met.

The port measures its performance. Such measurement has been focused on productivity indicators even though Bowersox and Closs (1996) suggest that logistics performance can be compared against other classes of performance measures, namely, cost, customer service, asset management, and quality.

Academic research has largely used the concept of efficiency to assess performance. In port literature Talley, Wang and al. discussed three types of efficiency: technical and overall efficiency. Technical efficiency is defined as 
achieving higher productivity given available inputs or production at the least possible cost per unit of output.

Rather than port service variables, we used twenty-foot equivalent container units (TEUs) to represent the effectiveness of ports. Either profitability or throughput seems to be a reasonable measure of effectiveness.

Several research studies have been done on logistics indicators and port performance indicators according to (Bichou, 2006).

Most of the existing port sector research referring to performance evaluation focuses on place assessment and productivity analysis of container terminals; other work seeks to identify criteria and measures for assessing the overall efficiency of ports (Bichou, 2007).

Brooks (2006) draws attention to the choice of performance indicators, in the sense that it classifies them into three categories:

- Physical indicators on time measurements and are mainly related to ships. Example: waiting time

- Productivity indicators that measure the resources needed to load or unload goods from a ship.

- Financial and economic indicators: such as the operating result achieved

\subsection{Port logistics integration}

The role of ports in supply chains grew in importance over the last decade. Due to changing customer needs and the willingness of shipping companies to improve operational efficiency, the integration of ports into supply chains becomes necessary (Robinson, 2006).

Several studies have used surveys to find port integration measures. It shows that information and communication technologies, intermodal or multimodal integration, value-added services, supply chain integration practices (Panayides and al., 2008; Tseng and Liao, 2015), user relations and organizational integration (Bichou and Gray, 2004; Panayides and Song, 2013) are the most relevant aspects for measuring the integration of ports into the supply chain.

Tseng and Liao (2015) find that integration with supply chain partners improves the speed of business processes and performance.

Also, through integration, ports, and terminals can improve their competitiveness and strengthen their services (Franc and Van der Horst, 2010).

Over the past two decades, the role of information technology in port systems has already been recognized by most experts. Information technology is a crucial element for improving operational cargo handling systems in the transfer and processing of large volumes of data within port organizations. 
Some studies have addressed the role of information systems in logistics (Panayides, 2017and Heilig and Vob, 2017). New directions in the logistics and supply chain are dictated by information technology. The use of information systems in ports improves its competitiveness (Panayides, 2017).

The use of information systems in container terminals has reduced manual effort and paper flow. It facilitated the timely flow of information and improved control and management of information. Port efficiency, therefore, depends largely on information technology applied to services.

Regan and Golob (2000) study found that information systems can reduce delays inside and outside ports. Congestion negatively affects business activities, while the adoption of information systems significantly reduces the problem of congestion within ports.

\section{Research methodology}

This research adopted a descriptive survey design. The impact of information technology on port performance was a cross-sectional study and it used a quantitative research approach.

The population targeted for the study comprised of executives of the National Ports Agency (responsible for information system management, head of the development of infrastructure), the executives in the terminal operators (Marsa Maroc), responsible for customs, representative of the association of freight forwarders, representatives of export companies and shipping agents.

The study adopted a qualitative exploratory and descriptive study carried out using the semi directive interview and primary data which were collected through a survey.

The research objective was to assess the relationship between information technology and performance. Data collected from the study was imported into a statistical package for social sciences (SPSS) for analysis using descriptive statistics.

\section{Presentation of the results}

\subsection{Port of Agadir}

The port of Agadir is specialized in container traffic, conventional and liquid bulk and among its main products such as citrus fruits, vegetables, and frozen fish.

It was essentially dedicated to fishing, now it has become a port complex that brings together the fishing port and the commercial port.

The commercial port provides economic operators with all the port infrastructures. It provides specialized facilities for refrigerated containers of citrus fruits, vegetables and frozen fish with automated management of the container terminal. Also within the framework of the services related to the goods, the port of Agadir offers all the infrastructures, the superstructures, the 
equipment, and the logistics necessary for the handling and unloading operations.

The infrastructures of the Agadir port complex are composed among others of $5 \mathrm{~km}$ of linear of quay including $1300 \mathrm{ml}$ intended for the commercial activities and the rest of the activities of fishing.

Principal actors of the Agadir port:

$>$ Port Authority: National Port Agency (ANP).

$>$ Terminal operating companies: Marsa Maroc.

$>$ Freight forwarders.

$>$ Shipping companies.

\subsection{Port Information System:}

As part of the "Morocco Numeric 2013" strategy, launched in 2009, which aims to develop the use of Information and Communication Technologies; the aim of the "e-Gov" axis of this strategy is to get citizens and businesses closer to administrations in a dematerialized relationship that combines efficiency with transparency.

PORTNET is an information system to the port community service which aims to ensure the competitiveness of Moroccan ports.

As part of its role as regulator and coordinator of the port community, the National Ports Agency has implemented a digital strategy that simultaneously benefits economic operators and strengthens the competitiveness of the sector.

The various information systems of these public and private partners are now connected through "PORTNET", which allows optimized operational management of the flow of goods and corresponding document flows. 


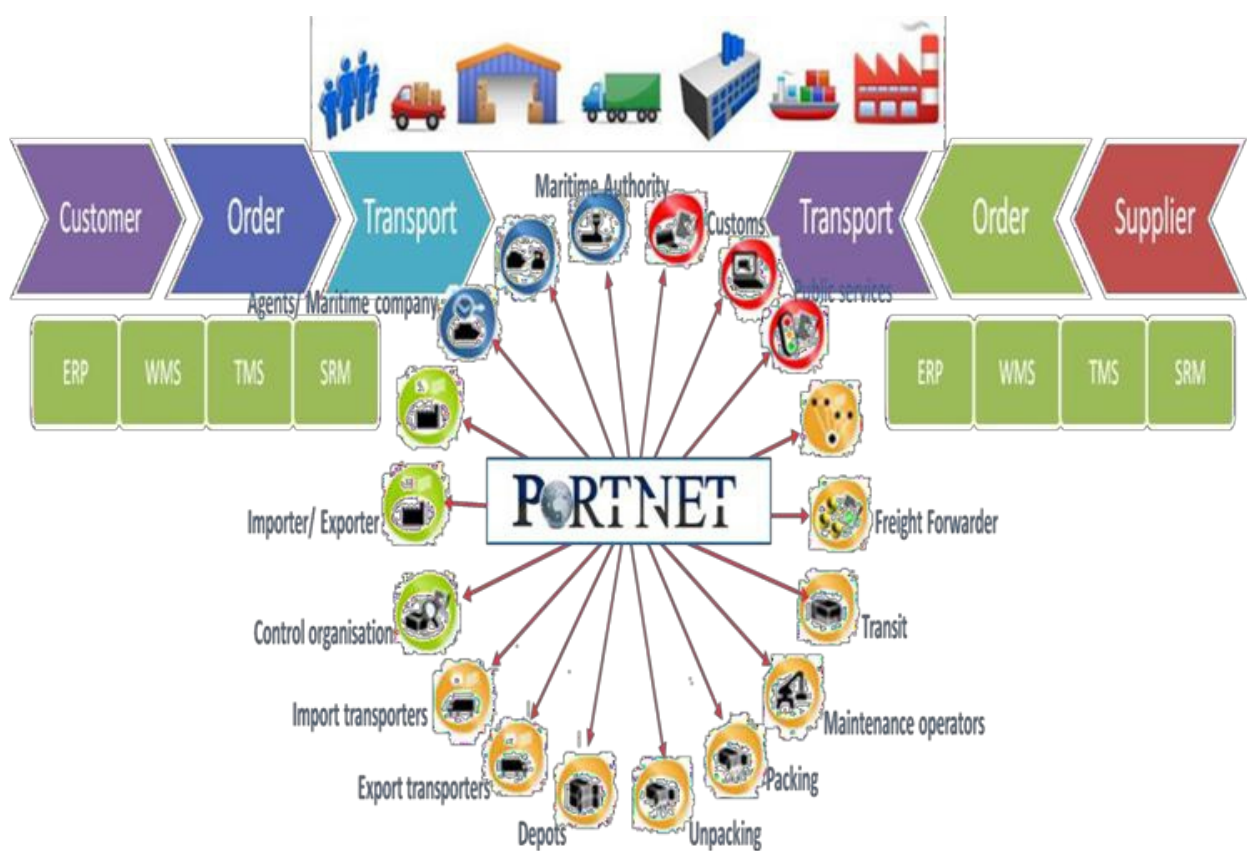

Fig -1: Integration of the port chain: Actors of the port Community

Advances in information technology offer a wide range of options for the container terminal operator to automate his information system. The integration of the information system has reduced manual effort and paper flow facilitated the timely flow of information and contributed to improving control and management of information.

The importance of information technology, including the Internet, in supply chain management, has facilitated the exchange of information in commercial transactions between businesses and individuals, as well as the improvement of growth and profitability along the supply chain.

PORTNET is an EDI system that provides port users with an electronic system. With this system, port users have convenient access to information. The users can also interact electronically. The system reduces the delivery time of ships and facilitates procedures to port customers.

\subsection{The elements of the information system that contributed to port performance}

The complete integration of the logistics chain of external trade, the one- stop-shop ensures the connection of economic operators with suppliers of public and private services. They are therefore able to manage, through just one-stop-shop, all of the procedures in the external trade chain.

The National Ports Agency (ANP) is deeply committed to an ambitious digital strategy. Their plan will respond to the challenges facing the port sector 
and meet the expectations of both public and private actors within the community.

PORTNET is an EDI system that provides port users with an electronic system. With this system, port users have access to information. Introducing new technologies to contribute to port performance and competitiveness

The dematerialized port processes are as follows:

- Optimization of procedures;

- Traceability of operations (safety);

- Electronic payment system;

The Customs representative reiterated the importance of PORTNET to interact with the various stakeholders as a facilitator. This dematerialization made it possible to make the shipments more fluid.

\subsection{Information system and performance:}

Information systems contribute to the overall performance of a port by enabling the coordination of actors and the standardization of procedures. The dematerialization of this phase of the port of Agadir has already allowed:

- Facilitating and organizing access to export containers;

- Synchronize efforts between the various stakeholders in the process;

- Have optimal management of storage, sequence, and loading;

- Anticipate and optimize the allocation of human and material resources;

The adoption of an information system enables continuous improvement of the performance of the Agadir port transit chain, in particular by reducing the waiting time of vessels, which improves port productivity.

The savings in terms of cash flow and waiting time for goods are very important. The continuous and real-time measurement of performance indicators is critical to achieving expected performance levels and improving the overall quality of service. Statistical data are published by the ANP every month on all port activities in Morocco.

PORTNET also produces a monthly, weekly and daily dashboard to highlight the operational performance of import/export processes. 
Table -1: Performance indicators

\begin{tabular}{|c|c|c|}
\hline Performance indicators & $\begin{array}{c}\text { Before the adoption of } \\
\text { community information } \\
\text { system }\end{array}$ & $\begin{array}{c}\text { After the adoption of a } \\
\text { community information } \\
\text { system "PORTNET" }\end{array}$ \\
\hline $\begin{array}{c}\text { The average time between } \\
\text { unloading containers and the } \\
\text { filing of the goods declaration }\end{array}$ & 75 hours & 64 hours \\
\hline Average container staying & 7.9 days & 30 hours \\
\hline Average container handling & 35 hours & \\
\hline
\end{tabular}

New information systems solutions have been developed to increase the efficiency of ports.

Performance is a priority of the port strategy in Morocco. This study, therefore, examined the role of information systems in improving performance. The study states that the adoption of the PORTNET information system improves the operational performance of the port of Agadir, in particular:

$>$ A reducing vessel waiting time;

$>$ Decrease in the staying time of vessels;

$>$ Improvement of average productivity at the berth;

The Port Authority plays the most important role as initiator and creator of the port development strategy, and as coordinator of the entire port community. The Port Authority is a land manager responsible for the safe, sustainable and competitive development of the port.

\section{Conclusion}

Today, ports are considered critical nodes in a global offering that provides an intermodal transport system. In a highly competitive environment, it is necessary to be effective. The exchange of information is necessary and, therefore, the ports are using more and more of the state-of-the-art technology services information. This study is purely exploratory.

The paper evaluates the evolution of port performance with the introduction of the port information system. The results concluded that the performance has been improved with the adoption of the system port information called "Portnet" in the port of Agadir.

\section{References:}


1. Bichou, K. (2006). Chapter 24 Review of Port Performance Approaches and a Supply Chain Framework to Port Performance Benchmarking . Research in Transportation Economics, Elsevier, 17(1), 567-598.

2. Bichou, K. (2007). Review of Port Performance Approaches and a Supply Chain Framework to Port Performance Benchmarking. In: Cullinane, K., Ed., Devolution, Port Governance and Port Performance, Research in Transportation Economics, Elsevier, 17, 567-598.

3. Bowersox, D. J., \& Closs, D.J. (1996). Logistical Management: The Integrated supply Chain Process. McGraw-Hill College.

4. Franc ,P., \& Van der Horst M. (2010).Understanding hinterland service integration by shipping lines and terminal operators: A theoretical and empirical analysis. Journal of Transport Geography ,18(4),557-566.

5. Heilig, L., \& Voß, S. (2017). Information systems in seaports: a categorization and overview. Information Technology and Management, 179-201.

6. Hsu, H.J., \& Lalwani, C.S. (2010). ICT Implementation in Facilitating International Transport Proceedings of the International Forum on Shipping, Ports and Airports (IFSPA), 15-20.

7. Kia, M., Shayan, E., \& Ghotb, F. (2000). The importance of information technology in port terminal operations. International Journal Physical Distribution \& Logistics Management, 331-344.

8. Meersman, H., Van de Voorde, E., Vanelslander, T. (2009). Future challenges in the port and shipping sector. Grammenos Library. Informa Law: London.

9. Mentzer, J. T., \& Konrad, B. P. (1991).An efficiency effectiveness approach to logistics performance analysis. Journal of Business Logistics,33-62.

10. O’Brien, J. A., \& Marakas, G. (2011).Management Information Systems. McGraw-Hill Higher Education.

11. Regan, A. C. \& Golob, T. F. (2000). Trucking industry perceptions of congestion problems and potential solutions in maritime intermodal operations in California. Transportation Research Part A:Policy and Practice,Elsevier,34(8),587-605

12. Reix, R., Fallery, B., Kalika, M., \& Rowe, F. (2016).Systèmes d'information et management.

13. Robinson, R. (2002).Ports As Elements in Value-Driven Chain Systems: The New Paradigm. Maritime Policy and Management, 29(3), 241-255. 
14. Rodon, J. ,\& Pujol, R. (2006).Exploring the intricacies of integrating with a port community system.

15. Song, D. W., \& Panayides, P. M. (2007). Global supply chain and port/terminal: integration and competitiveness. The International Conference on Logistics, Shipping and Port Management.

16. Sweeny, E., \& Evangelista, P. (2005). Port Community Learning Needs: Analysis and Design, 27-43.

17. Talley, W.T. (2006). Port Performance: An Economics Perspective, in Brooks M.R. and Culliname K. (ed.), Devolution, Port Governance and Port Performance, Research in Transportation Economics, 17, 499-516.

18. Tijan, E., Agatić, A., \& Hlača, B. (2012). The Necessity of Port Community System Implementation in the Croatian Seaports, PrometTraffic \& Transportation Conference.

19. Tseng, P.H., \& Liao, C.H. (2015).Supply chain integration, information technology, market orientation and firm performance in container shipping firms. International journal of logistics management. 